\title{
Improvement of Vehicle Service System by the Application of Lean Six Sigma
}

\author{
Natcha Thawesaengskulthai ${ }^{\mathrm{a}}$ and Patiphan Jarumanee ${ }^{\mathrm{b}, *}$ \\ Department of Industrial Engineering, Faculty of Engineering, Chulalongkorn University, Bangkok 10330, \\ Thailand \\ E-mail: aNatch_T@chula.c.th, bYindeeteedairujakkub@hotmail.com (Corresponding author)
}

\begin{abstract}
This research aims to improve the efficiency of vehicle service system in Faculty of Engineering, Chulalongkorn University. The study adopted the lean six sigma methods with DMAIC process and New Service Development by following 5D steps which are Discover, Define, Design, Develop and Deploy. In this process, the Lean Six Sigma or DMAIC is implemented and considered as the main tool which is used together with the development of service innovation in order to equip the tools with fully developed characters. The occurred problems and its root causes were discovered and defined by using SERVQUAL questionnaires to evaluate customer satisfaction levels to 20 service dimensions. Innovative solutions were generated by using the Quality Function Deployment (QFD) and lean techniques. The action plan includes: 1) developing a vehicle reservation system which can be done via intranet, 2) redesigning the back-end procedure by applying the ECRS principle and developing the manual, 3) improving the quality control and assessment system, 4) developing a new working standard for customers and drivers. After the implementation of this new system, the car users were satisfied with the service as the score (1-5 Likert scale) increased by 30\% from 3.35 as the medium level to 4.37 as the good level. The time of check back system is decreased by $87 \%$ from 15.5 minutes to 2 minutes
\end{abstract}

Keywords: Lean six sigma, new service development, vehicle service system.

ENGINEERING JOURNAL Volume 20 Issue 2

Received 8 June 2015

Accepted 14 September 2015

Published 18 May 2016

Online at http://www.engj.org/

DOI:10.4186/ej.2016.20.2.159 


\section{Introduction}

The competition for the success of the service, in both private and public sectors must be concerned in order to respond quickly and meet the customer's satisfaction. The government reforming policy lets the agencies develop the process effectively, reduce the operations to no avail, and respond to public services quickly to make them satisfied. Therefore, the administration of the government can improve the performance and make it as effective as possible.

Innovation development is conducted by collecting data from multiple sources such as feedbacks from clients, keeping statistics, and applying new technologies to encourage the development. [1]

The key variable which contributes to the growth of service and progress is the information technology. It is considered as one of the most important parts to the organization. The application of information technology helps develop a better system with increased productivity, reduced waste, higher profit, and an increase in the level of satisfaction of clients. [2]

A method used to reduce the waste that occurs in the service has adopted the idea of Lean Six Sigma as a tool to help reduce the duration of each process, the variability that occurs, and improve the service quality $[3,4]$. Hence, the Lean Six Sigma theory focuses on eliminating wastes in the process which uses the concept of value added to the activities held. Moreover, the Lean Six Sigma aims at improving the efficiency of operations by creating a flow of work throughout the process continuously by using statistical tools to analyze [5]. Therefore, to achieve these goals, there must be an identification of waste which includes activities, procedures or non-value added processes focusing on the needs of customers with high quality standard and satisfaction. [6]

QFD is a tool for transformation of customer requirements into products and services. [7] Start at hearing the voice of customers and relayed to design products that client's needs. The design of service and contribute process required to satisfy of client. QFD is an important tool which organizations need to learn the basics and then applied to the system. [8] This tool was applied from manufacturing industry to service industry such as communication industry [9], hotel [10], hospital [11] etc.

SERVQUAL is used as a diagnostic technique for uncovering broad areas of an organization's service quality strengths and weakness. [12] The model consists of the following five dimensions:

1. Tangible - physical facilities, equipment, and the appearance of personnel.

2. Reliability - ability to perform the promised service accurately and dependably.

3. Responsiveness - willingness to help customers and to provide prompt service.

4. Assurance - knowledge and courtesy of employees and their ability to convey trust and confidence.

5. Empathy - caring and individualized attention to customers.

In this process, the Lean Six Sigma or DMAIC is implemented and considered as the main tool which is used together with 5D step of new service development [1] in order to equip the tools with fully developed characters, as shown in Fig. 1.

The objectives of this study as following:

1. To develop service innovation for the vehicle service system

2. To create a system that can track and check vehicles which are being or have been served.

3. To create a manual for reserving vehicles.

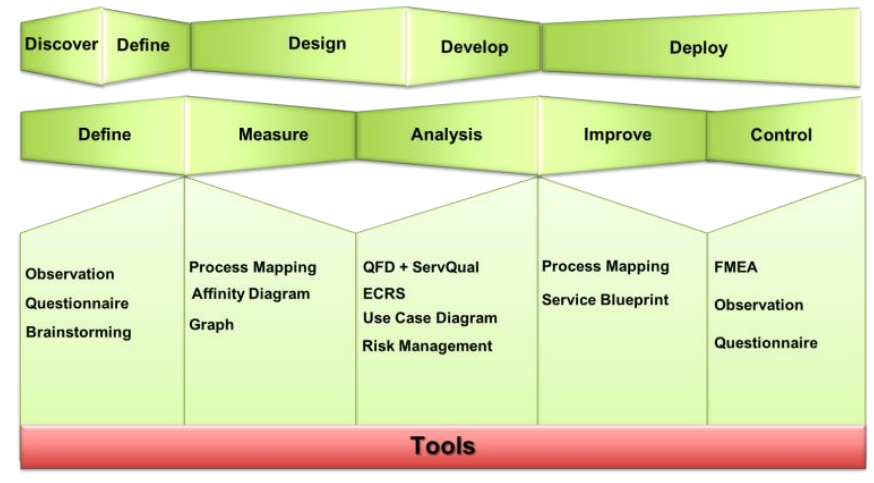

Fig. 1. Methodology and tools. 


\section{Define}

The department of Organization and Development, Faculty of Engineering, Chulalongkorn University, has determined to be a supporting agency that responds to the faculty's strategy with a well-flowing service and effective management.

As a result of such policy, it is made necessary to format the work processes to assist the operations within the Faculty. In addition, it helps increase the efficiency and reduces waste to make the process flow fluently; thus, teachers, students and staff of the Faculty are satisfied with the work process.

Improving the service of vehicle reservation system in Faculty of Engineering, Chulalongkorn University is one of the projects that the Board intends to implement. The reservation process was considered as a supporter of the work and obtained a satisfaction score of 3.32 in 2013 (see Fig. 2) which was good as compared to other departments. However, the supporting department had the 5th least score of satisfaction among 7 departments that obtained a satisfaction score of 3.35 and considered as a standard level.

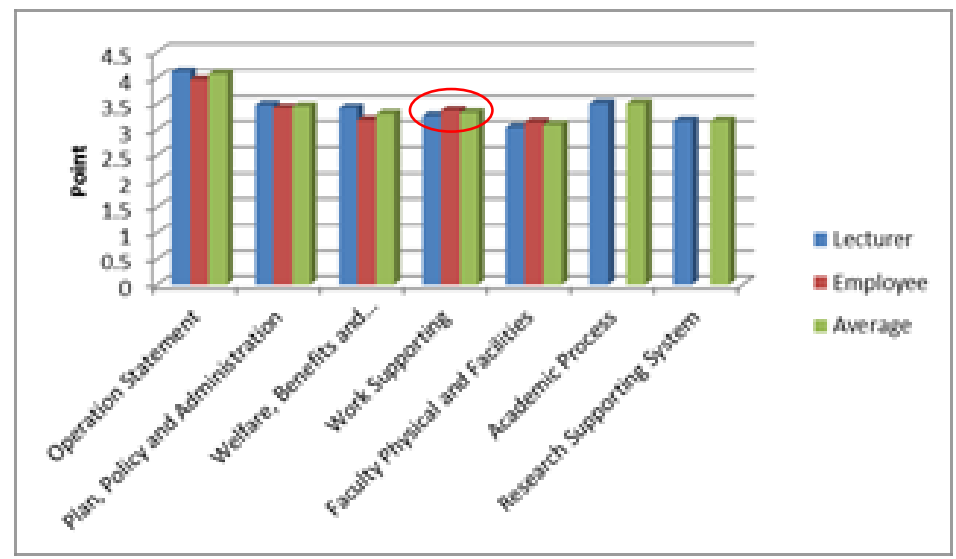

Fig. 2. Satisfaction of employees.

\section{Measure}

The vehicle reservation procedure is divided into two patterns: 1. Travelling in Bangkok and perimeters, and 2. Travelling to other provinces (see Figs. 3 and 4 respectively).



Fig. 3. Process of travelling in Bangkok/Perimeter. 


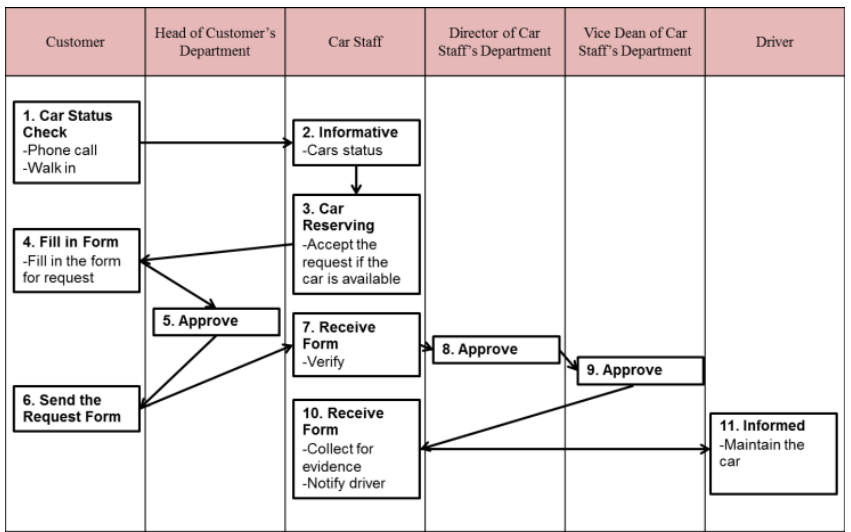

Fig. 4. Process of travelling to other provinces.

According to the study on vehicle service of the Faculty of Engineering which was conducted by interviewing the vehicle staff, Director of management, Head of Human Resource, students, and employees, it is found that problems mainly occur in the case of cars travelling in Bangkok and perimeters. The reason for causing the problems was because travelling to other provinces had to be approved by the Associate Dean. As a result, more strict procedures were followed by the official staff comparing with travelling within Bangkok and perimeters. In the later case, the official staff could be authorized to approve the car himself and the faculty staff usually book cars in advance even they may not use them on the actual date. This practice could cause problems for those who need a car indeed. Although there are forms that needs to be filled by car users, most of them prefer booking by calling the staff as it is more convenient, faster, and no need to waste time in filling the forms. In some cases, they complete the forms but do not provide necessary information. Consequently, the mentioned action caused problems to other staff who wanted to use cars and the building agencies caused injustice because they could not monitor the exact date and time, so it was difficult to specify a standard operating procedure clearly. There was also conflict caused among the car users as some of them knew the staff and had an opportunity to intervene the queue, or the staff allocated the drivers to leave for trips unequally. As a result, working hours and salary were given unequally as shown in Fig. 5, which was not unveiled and did not indicate any errors. It also led to an unsystematic work process of the premises agency department because collecting documents filled by car users voluntarily was regarded as unimportant. Accordingly, it was impossible to correct mistakes or errors.

There are several points noted to solve the problems as follows:

- Problems in car usage regulations

- Problems in the work process

- Car usage approval problems

- Documentary problems

- Driver problems

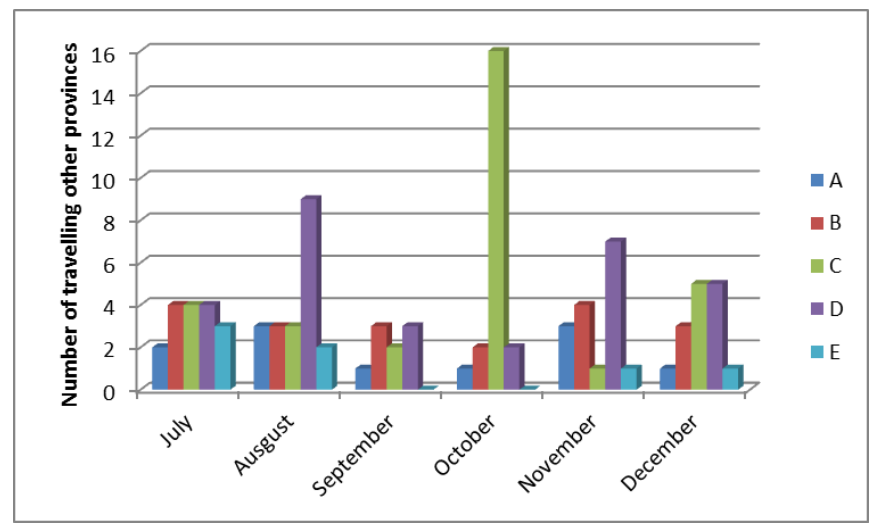

Fig. 5. Workload of drivers for travelling to other provinces.

Based on the brainstorm with organizations relevant to the vehicle service, a questionnaire was made to investigate what the service user want regarding the surveyed problems. Table 1 summarizes the issues that service users think need improvement. 
Table 1. Customer Requirements.

\begin{tabular}{|c|c|}
\hline $\begin{array}{l}\text { Servqual } \\
\text { Dimensions }\end{array}$ & Customer Requirements \\
\hline \multirow{5}{*}{ Reliability } & 1. All complaints are taken into consideration and action. \\
\hline & 2. The procedure of vehicle reservation should be easily understandable. \\
\hline & 3. The service has to be always good. \\
\hline & $\begin{array}{l}\text { 4. The service should have suitable stops and send the passengers to the desired } \\
\text { destination. }\end{array}$ \\
\hline & 5. The reservation process should be fast. \\
\hline \multirow{5}{*}{ Tangibles } & 6. Vehicle should be equipped with magazines, newspaper, etc. \\
\hline & 7. Both inside and outside of the passengers' compartment are always clean. \\
\hline & 8. The vehicles must be of good condition, including the devices inside. \\
\hline & 9. Staffs wear proper outfit. \\
\hline & 10. Operation and reservation procedures should be clear and easily understandable. \\
\hline \multirow{4}{*}{ Responsiveness } & 11. Service users should be able to cancel the reservation when unable to travel. \\
\hline & $\begin{array}{l}\text { 12. There should be a channel to send complaints, ask questions, or give feedback for } \\
\text { further improvements. }\end{array}$ \\
\hline & $\begin{array}{l}\text { 13. Actual operation of the vehicles should be as scheduled and punctual. In case of } \\
\text { emergency that may delay the operation, the vehicle staff has to fix the problem in a } \\
\text { timely manner and inform the service users. }\end{array}$ \\
\hline & 14. Staffs should be willing and prepared to provide service. \\
\hline \multirow{4}{*}{ Assurance } & 15. Vehicle staffs should provide service in a polite manner and assistance as appropriate. \\
\hline & $\begin{array}{l}\text { 16. Staffs are able to fix the problem at hand that might happen, for example, when the } \\
\text { vehicle is out of order or there is an accident during the ride. }\end{array}$ \\
\hline & $\begin{array}{l}\text { 17. Staff should do, suggest, and find a space for belongings which should not be at the } \\
\text { risk of being damaged or lost during the ride, and there should be a system to prevent } \\
\text { forgetting the belongings. }\end{array}$ \\
\hline & 18. The service provision should be transparent. \\
\hline \multirow[t]{2}{*}{ Empathy } & $\begin{array}{l}\text { 19. Passengers should be taken care of and welcomed with hospitable manner and } \\
\text { gratitude. }\end{array}$ \\
\hline & 20. St \\
\hline
\end{tabular}

\section{Analysis}

The results are applied to a modified variant of quality function technique QFD and SERVQUAL together via Microsoft Excel by the process of implementation according to Fig. 6. The implementation of modified variant of quality function technique and SERVQUAL to compile the data in terms of needs and expectations of the customers is more efficient with QFD in order to improve and design services because QFD has advantages in linking customers' needs with what need to be improved.[13, 14] In addition, the original QFD was not concerned with how to keep the data, so two models are applied together by considering the risks to improve and design a new service process in the area of finance and time. The results from applying QFD and SERVQUAL will enable QFD to be more efficient and suitable for service industry. Step of QFD and Servqual as shown in Fig. 6 and the results of the operation as shown in table (Table 2). 


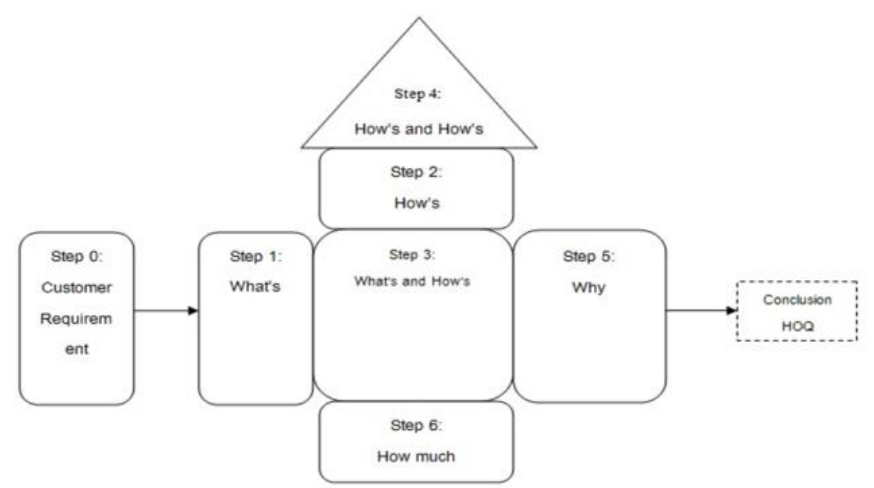

Fig. 6. Step of QFD + ServQual.

Explanation of each step [15] as follows:

Step 0: Customer requirement

First step of QFD is to identify the customer. The voice of customer includes from sources such as manufacturing, purchasing, suppliers etc. Then collect the data relating customer requirement. These include interview, survey, feedback and statistical record.

Step 1: What's

\section{Customer requirement}

Customer needs are divided into five groups of SERVQUAL dimensions which are Reliability, Tangible, Responsiveness, Assurance and Empathy.

(1.2) Self-state importance

Calculation of the importance level from customer needs can be done as follows :

$$
\text { Self-State Importance } j=\frac{\sum x_{i j}}{n_{i}}
$$

where $\mathrm{i}$ is the respondent No. $\mathrm{i}$;

$\mathrm{j}$ is the requirement issue No. $\mathrm{j}$;

$\mathrm{x}_{\mathrm{ij}}$ is the scoring of self-state importance, person No. i about requirement No. $\mathrm{j}$;

$\mathrm{n}_{\mathrm{j}}$ is the number of respondents to the requirement issue No. $\mathrm{j}$.

(1.3) Service quality expectation:

Calculation on the ratio of the service quality expectation compared with the actually received service. The information will be obtained from the data collection above. It is possible to calculate to find Service Quality of Expectation (SQE) of each requirement as follows:

$$
\text { Service Quality of Expectation }(\mathrm{SQE})=\text { Expectation }(\mathrm{E}) \div \text { Perception }(\mathrm{P})
$$

As for the analysis of Service Quality Expectation (SQE), calculation to find the average value can be done from Geometric Mean as follows:

$$
S Q_{j}=\left[\prod_{i=1}^{n_{j}}\left(\frac{E_{i j}}{P_{i j}}\right)\right]^{1 / n_{j}}
$$

Adjust importance

$$
\mathrm{SQEj} * \text { Self State importance }
$$


Step 2: How's

Technical requirement:

Put the technical requirements that will meet customer needs in each item. This can be divided into eight main parts for service (The Flower of Service) namely Information, Payment, Billing, Order-Taking, Consultation, Exception, Safekeeping and Hospitality [16].

\section{Improvement direction:}

Put the manner of direction for developing the targets of technical requirements by using the following symbols.

$$
\begin{aligned}
& =\text { Objective is to maximize } \\
& =\text { Objective is to hit target } \\
& =\text { Objective is to minimize }
\end{aligned}
$$

Step 3: What's and How's

The third step is to relate customer requirements with technical requirement where

$$
\begin{array}{ll}
\triangle \text { or } 1 & =\text { Weak relationship } \\
\bigcirc \text { or } 3 & =\text { Moderate relationship } \\
& \text { or } 9
\end{array}
$$

Step 4: How's and How's

This is the roof of the House of Quality which represents the relationship between technical requirements of different types (Correlation Matrix) to know how they play a part in supporting or confuting each other so as to help solve the problems in the design. It is possible to indicate the correlation between technical requirements by using the symbols as follows:

$$
\begin{array}{ll}
++ & =\text { Strong Positive Correlation } \\
+ & =\text { Positive Correlation } \\
\text { Blank } & =\text { Without Correlation } \\
- & =\text { Negative Correlation } \\
-- & =\text { Strong Negative Correlation }
\end{array}
$$

Step 5: Why

This part is on the right-hand side of the House of Quality. It is used for strategic planning because it contains information about the survey of customers' opinions between the product / service of competitors and ours, assessment of selling points. It is composed of the following sub- steps.

$$
\text { Our: }
$$

Analysis of ourselves by assessing the level of customer satisfaction with our customer needs at present. The 1 - 5 scale is used as basis for evaluation. The level 5 of scale means that the customers are satisfied with the company that can meet customer needs in highest level.

$$
\text { Competitor: }
$$

Analysis of competitor by evaluating the level of customer satisfaction with customers' needs of competitor. The 1-5 scale is used as basis for assessment likewise. 
Competition ratio:

$$
\text { Competition Ratio }=\frac{\text { Competitor }}{\text { Our }}
$$

(5.4) Absolute requirement weight:

$$
\text { Absolute Requirement weight }=\text { Adjust importance } * \frac{\text { Competitor }}{\text { Our }}
$$

(5.5) Relative requirement weight:

$$
\text { Relative Requirement weight }=\frac{\text { Absolute Requirement weight }}{\sum \text { Absolute Requirement weight }} * 100
$$

Step 6: How much

This section is at the bottom of the House of Quality. It is used in assessing the target value, including the risk to achieve the value as targeted. It includes the following sub-steps.

$$
\text { Target value: }
$$

Determination of the target value of technical requirements as to how the target is characterized. The target value must be measurable and often expressed in numerical terms.

Risk:

Determination of the risk that will occur in the development of technical requirements to meet the specified target in numerical terms for use in analysis and selection to take the technical requirements for use. In this place, two points of view will be taken into consideration namely

- Time

- Cost

(6.3) Absolute technical weight:

Absolute Technical weight $=\sum($ Interrelationship*Absolute Requirement weight $)$

(6.4) Relative technical weight:

$$
\text { Relative Technical weight }=\frac{\text { Absolute Requirement weight }}{\text { ¿Absolute Requirement weight }} * 100
$$

Table 2. Result of QFD + ServQual.

\begin{tabular}{lc}
\hline Technical Requirements & Point \\
\hline Create reservation on information technology & 7.98 \\
Show status of vehicle & 7.09 \\
Create manual of reserve vehicle & 7.05 \\
Create transparent/reliability & 6.95 \\
Improve process of reservation & 6.88 \\
Create ordering/ finishing reservation paper & 6.51 \\
Improve preparedness of vehicles and drivers & 5.64 \\
Trace back of reservation detail & 5.42 \\
Improve assessment form & 5.40 \\
Help more than regular & 5.37 \\
Greeting and personality & 5.37 \\
Advice for customers & 5.19
\end{tabular}


Reduce process time

Create receipt (travel by personal and renting vehicle) $\quad 4.78$

Collect of drivers and vehicle statistics $\quad 4.54$

Make standard of reservation and drivers $\quad 3.05$

Knowledge of route $\quad 2.24$

Devices in vehicle $\quad 2.08$

More entertainment $\quad 1.73$

More facilities $\quad 1.55$

According to the results of applying QFD and SERVQUAL techniques, the researcher has searched for the way to improve according to the results above (Table 3).

Table 3. Improvement plan.

\begin{tabular}{llc}
\hline Propose of Improvements & Technical Requirements & Point \\
\hline \multirow{3}{*}{$\begin{array}{l}\text { Create reservation system } \\
\text { via Intranet (Chulalongkorn } \\
\text { University's Database) }\end{array}$} & Create reservation on information technology & 7.98 \\
\cline { 2 - 3 } & Show status of vehicles & 7.09 \\
\cline { 2 - 3 } & Create transparent/reliability & 6.95 \\
\cline { 2 - 3 } & Create ordering/finishing reservation paper & 6.51 \\
\cline { 2 - 3 } Improve process & Collecting of drivers and vehicles statistics & 4.54 \\
\cline { 2 - 3 } & Improve process of reservation & 6.88 \\
\cline { 2 - 3 } $\begin{array}{l}\text { Create manual of } \\
\text { reserve vehicle }\end{array}$ & Reduce processing time & 5.17 \\
\cline { 2 - 3 } & Create manual of reservation vehicle & 7.05 \\
\hline Improve assessment & Advice for customers & 5.19 \\
\cline { 2 - 3 } for customers & Create receipt (travel by personal and renting vehicle) & 4.78 \\
\hline \multirow{2}{*}{ Train staffs } & Retrace back of reservation & 5.42 \\
\cline { 2 - 3 } & Improve assessment form & 5.40 \\
\cline { 2 - 3 } & Improve preparedness of vehicle and drivers & 5.37 \\
\cline { 2 - 3 } & Grelping more than regular & 5.37 \\
\hline
\end{tabular}

\section{Improve}

After results of QFD + ServQual, the researcher proposes four improvement plans as following:

\subsection{Work Procedures Improvement}

The researcher has analyzed the problems from the process to determine the cause of problems and provide consistent communication system into the process i.e., the fishbone diagram. (see Fig. 7).

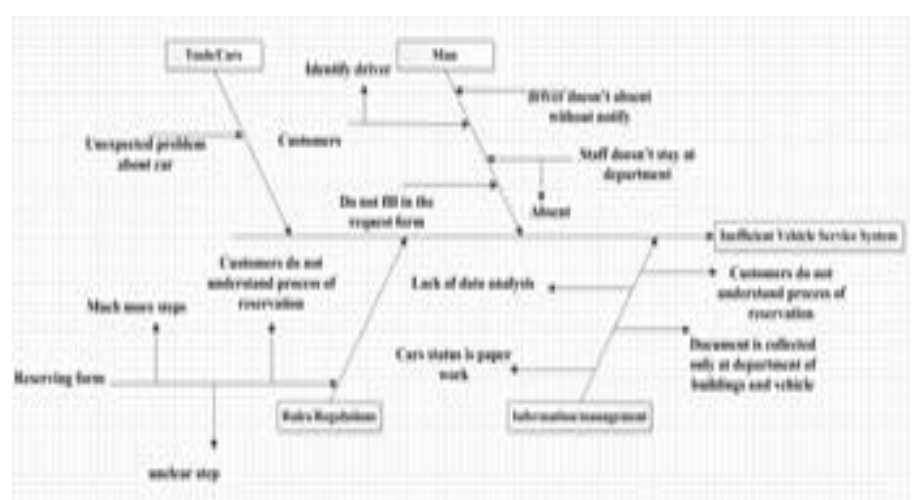

Fig. 7. Cause and effective diagram.

The main causes of problems were: 
- The vehicle reservation system management was still a documentation system which data collected from the reservations was kept at one place. Consequently, the applicants could not or check the status of vehicles by themselves.

- The applicants did not understand the procedures of vehicle reservation and did not provide the information clearly in the process of work improvement which aimed to reduce activity that did not have benefits but needed to be done (NNVA) and activity that did not provide benefits (NVA). It was because at that time, the vehicle reservation system was still using a documentation system in the whole process and there was no standard of work so there were losses from the process and errors found from the use of document. From the problems mentioned above, the researcher has presented the idea of improvement by using ECRS to help reduce waste from the process to be in accordance with the change from using document to communication system. Moreover, new work standard will be created by showing the improvement by using ECRS [17] (see Table 4).

Table 4. ECRS improvements.

\begin{tabular}{|c|c|}
\hline Method & Procedure \\
\hline $\begin{array}{c}\mathrm{E} \\
(\text { Eliminate) }\end{array}$ & $\begin{array}{l}\text { - Eliminate the process of answering the conditions of cars by letting the users check } \\
\text { by themselves. } \\
\text { The group of users travelling in Bangkok and perimeter provinces should eliminate } \\
\text { the step which the Head of Department/Official Department approve in case the } \\
\text { users are in the level of P7 or above. Hence, the users can be divided into } 2 \text { groups: } \\
\text { 1. Professors and staff with the level of P7 or above. And 2. Staff with the level of P6 } \\
\text { or below must be approved by the chief of the department } \\
\text { - Eliminate the process of communication between the staff in charge of the vehicles } \\
\text { and the drivers because the drivers can check the schedule via the system. }\end{array}$ \\
\hline $\begin{array}{c}\text { C } \\
\text { (Combine) }\end{array}$ & $\begin{array}{l}\text { - Submitting documents and making correction must be together by booking a car via } \\
\text { communication system and will not be able to proceed unless the data is completed. }\end{array}$ \\
\hline $\begin{array}{c}\text { R } \\
\text { (Rearrange) }\end{array}$ & $\begin{array}{l}\text { - Finish the documentary works and get them approved by the Head of Department } \\
\text { and attach to the petition. }\end{array}$ \\
\hline $\begin{array}{c}\text { S } \\
\text { (Simplify) }\end{array}$ & $\begin{array}{l}\text { - Increase the communication system ability for the staff and the executive to be able } \\
\text { to check the information, such as documents of the applicants to request for a car } \\
\text { with statistics, number of reservations, Utilization of drivers, results of satisfaction } \\
\text { evaluation etc. } \\
\text { - Automatically allocate job to drivers by considered statistic. } \\
\text { - Automatically sent e-mail to director and vice dean of car's department to approve } \\
\text { immediately. }\end{array}$ \\
\hline
\end{tabular}

Steps after the improvement are shown in Figs. 8, 9, and 10, respectively.

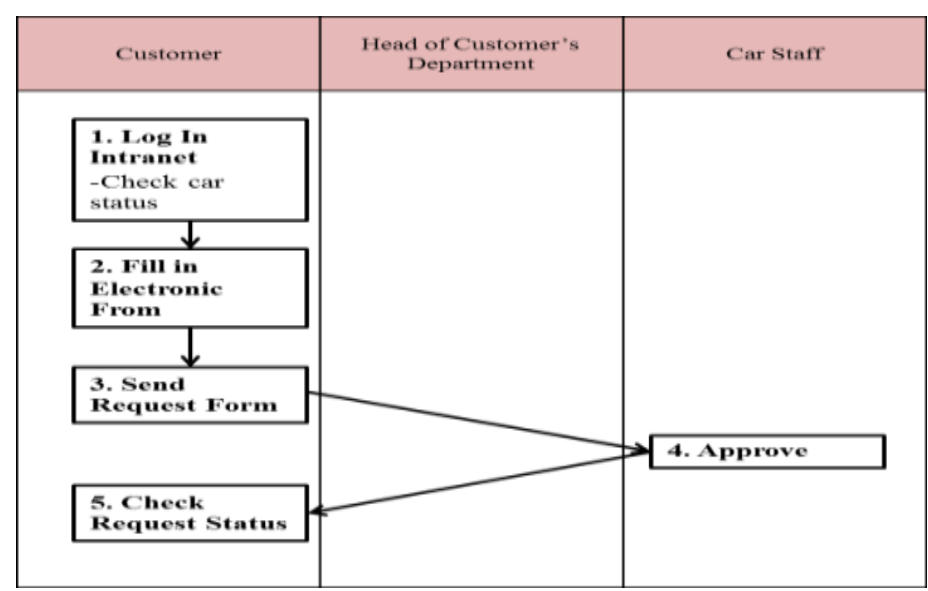

Fig. 8. Process of reservation in $1^{\text {st }}$ group for travelling in Bangkok/Perimeter. 


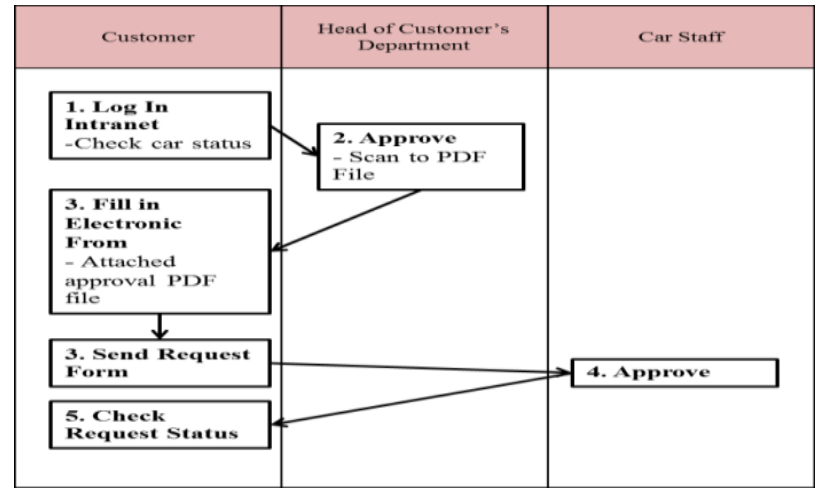

Fig. 9. Process of reservation in $2^{\text {nd }}$ group for travelling Bangkok/Perimeter.

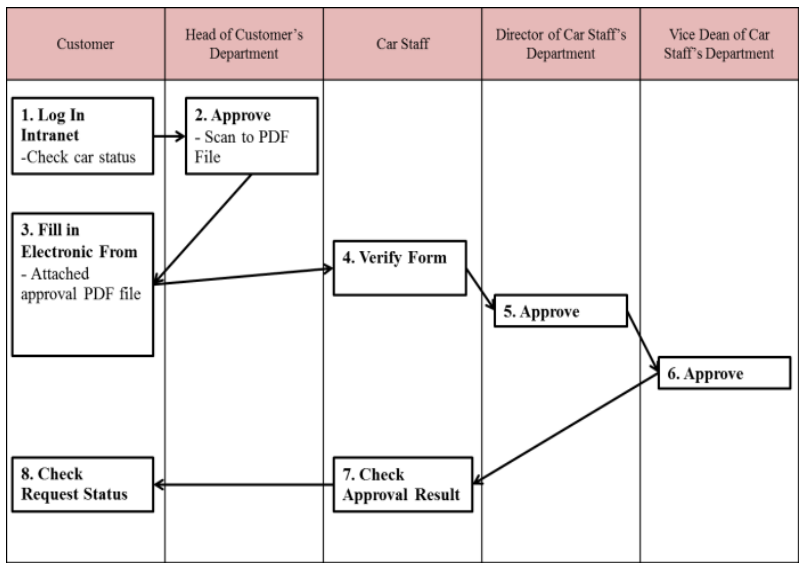

Fig. 10. Process of reservation for travelling other provinces.

\subsection{Applying Information System through via Intranet}

Reservation system via intranet helps solve problems that are unable to retrace in order to collect statistics. It can also solve the problems of paper usage, communication errors, and service concealment. The information system has changed from the old one (the system could allocate the driver with the petition automatically by evaluating wages and hours of work of each driver and compare with each other to get the most suitable choice of requirement).

Creating an information system for reservation is collaboration between Organization and Development Department and Information Technology Department that the Information Technology Department has a decision to implement the system. Researcher needs to follow a step shown in Fig. 11.

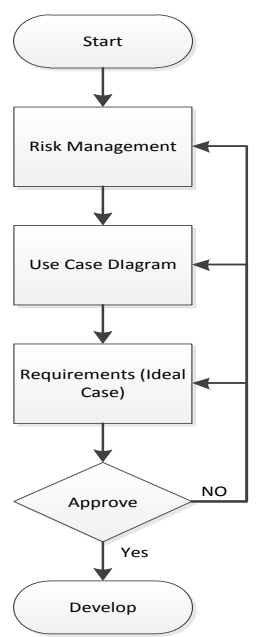

Fig. 11. Step of decision making by Information Technology Department. 
Risk management

Risk means any event or action that may occur with uncertain situation will impact the damage (both of monetary and non-monetary) or create failure to lose an opportunity of achieve the objectives and goals include strategic, operation, financial and compliance as measure by the impact received and likelihood of the situation. From definition can be divided risk into 4 types [18] as follows:
1) Strategic risk
2) Operation risk
3) Financial Risk
4) Compliance Risk

The analysis of risk management is shown in Table 5 and 6 respectively.

Table 5. Risk management.

\begin{tabular}{|c|c|c|c|c|c|c|}
\hline $\begin{array}{c}\text { Key Risk } \\
\text { Indicator } \\
\text { (KRI) }\end{array}$ & Likelihood & Consequences & $\begin{array}{c}\text { Risk } \\
\text { Value }\end{array}$ & $\begin{array}{l}\text { Risk } \\
\text { Level }\end{array}$ & Cause & $\begin{array}{l}\text { Improvement } \\
\text { Plan }\end{array}$ \\
\hline \multicolumn{7}{|l|}{ 1. Strategic Risk } \\
\hline $\begin{array}{l}\text { Users refuse to } \\
\text { use online } \\
\text { reserve system }\end{array}$ & Likely (4) & Major (4) & 16 & $\mathrm{E}$ & $\begin{array}{l}\text { Users acquainted } \\
\text { with old system } \\
\text { and not trusted the } \\
\text { new system. }\end{array}$ & $\begin{array}{l}\text { Publicize about } \\
\text { new system and } \\
\text { slowly move to } \\
\text { the new system }\end{array}$ \\
\hline $\begin{array}{l}\text { Participants } \\
\text { don't know } \\
\text { about new } \\
\text { system }\end{array}$ & $\begin{array}{l}\text { Possible } \\
\text { (3) }\end{array}$ & $\begin{array}{l}\text { Catastrophic } \\
\text { (5) }\end{array}$ & 15 & $\mathrm{E}$ & $\begin{array}{l}\text { No announcement } \\
\text { about new system }\end{array}$ & $\begin{array}{l}\text { Advertise } \\
\text { through Email } \\
\text { to participants }\end{array}$ \\
\hline $\begin{array}{l}\text { Users resist } \\
\text { using software }\end{array}$ & $\begin{array}{l}\text { Likely } \\
\text { (4) }\end{array}$ & $\begin{array}{l}\text { Catastrophic } \\
\text { (5) }\end{array}$ & 20 & $\mathrm{E}$ & $\begin{array}{l}\text { Caused by bias that } \\
\text { software is not } \\
\text { efficiency or } \\
\text { uselessness. }\end{array}$ & $\begin{array}{l}\text { Explain about } \\
\text { advantage of } \\
\text { software. }\end{array}$ \\
\hline $\begin{array}{l}\text { No survey about } \\
\text { users demand }\end{array}$ & $\begin{array}{l}\text { Likely } \\
\text { (4) }\end{array}$ & $\begin{array}{l}\text { Major } \\
\text { (4) }\end{array}$ & 16 & $\mathrm{E}$ & $\begin{array}{l}\text { No questionnaire } \\
\text { for participants }\end{array}$ & $\begin{array}{c}\text { Make } \\
\text { participants } \\
\text { questionnaire }\end{array}$ \\
\hline Unclear system & Possible (3) & $\begin{array}{l}\text { Major } \\
(4)\end{array}$ & 13 & $\mathrm{H}$ & $\begin{array}{c}\text { Unclear } \\
\text { requirement or } \\
\text { vendor is not } \\
\text { understand about } \\
\text { requirement } \\
\end{array}$ & $\begin{array}{l}\text { Make clearly } \\
\text { requirement }\end{array}$ \\
\hline $\begin{array}{l}\text { Vendor is not } \\
\text { understand } \\
\text { about concept } \\
\text { of software }\end{array}$ & Possible (3) & $\begin{array}{l}\text { Major } \\
(4)\end{array}$ & 12 & $\mathrm{H}$ & $\begin{array}{l}\text { Vendor is not } \\
\text { understand about } \\
\text { requirement }\end{array}$ & $\begin{array}{l}\text { Make sure that } \\
\text { vendor is } \\
\text { understood. }\end{array}$ \\
\hline \multicolumn{7}{|l|}{ 2. Operation Risk } \\
\hline $\begin{array}{l}\text { Users can not } \\
\text { use online } \\
\text { reserve system }\end{array}$ & $\begin{array}{l}\text { Likely } \\
\text { (4) }\end{array}$ & $\begin{array}{l}\text { Major } \\
\text { (4) }\end{array}$ & 12 & $\mathrm{H}$ & $\begin{array}{l}\text { Users do not know } \\
\text { how to use system. }\end{array}$ & $\begin{array}{l}\text { Make system } \\
\text { easy to } \\
\text { understand by } \\
\text { step-by-step } \\
\text { example. }\end{array}$ \\
\hline
\end{tabular}




\begin{tabular}{|c|c|c|c|c|c|c|}
\hline $\begin{array}{l}\text { Correction of } \\
\text { information } \\
\text { from users input }\end{array}$ & $\begin{array}{l}\text { Possible } \\
\text { (3) }\end{array}$ & $\begin{array}{l}\text { Moderate } \\
\text { (3) }\end{array}$ & 9 & M & $\begin{array}{c}\text { Caused by } \\
\text { imperfect design }\end{array}$ & $\begin{array}{c}\text { Design system } \\
\text { to cover all of } \\
\text { desire detail. }\end{array}$ \\
\hline $\begin{array}{l}\text { Duplicate or } \\
\text { spare } \\
\text { reservation }\end{array}$ & $\begin{array}{l}\text { Possible } \\
\text { (3) }\end{array}$ & $\begin{array}{l}\text { Moderate } \\
\text { (3) }\end{array}$ & 9 & M & $\begin{array}{l}\text { Or users not fill all } \\
\text { detail. }\end{array}$ & $\begin{array}{c}\text { Make a } \\
\text { reservation } \\
\text { status to tell } \\
\text { users }\end{array}$ \\
\hline \multicolumn{7}{|l|}{ 3. Financial Risk } \\
\hline $\begin{array}{l}\text { Financial } \\
\text { miscalculation }\end{array}$ & Possible (3) & $\begin{array}{l}\text { Catastrophic } \\
\text { (5) }\end{array}$ & 15 & $\mathrm{H}$ & $\begin{array}{l}\text { Financial analyze } \\
\text { misunderstanding }\end{array}$ & $\begin{array}{l}\text { Consult with } \\
\text { financial } \\
\text { consultant }\end{array}$ \\
\hline $\begin{array}{l}\text { Insufficient } \\
\text { budget for } \\
\text { project that } \\
\text { cause error } \\
\text { analyze at the } \\
\text { first place }\end{array}$ & $\begin{array}{l}\text { Possible } \\
\text { (3) }\end{array}$ & $\begin{array}{l}\text { Catastrophic } \\
\text { (5) }\end{array}$ & 15 & $\mathrm{H}$ & $\begin{array}{l}\text { Financial analyze } \\
\text { misunderstanding }\end{array}$ & $\begin{array}{l}\text { Consult with } \\
\text { financial } \\
\text { consultant }\end{array}$ \\
\hline \multicolumn{7}{|l|}{ 4. Compliance Risk } \\
\hline $\begin{array}{l}\text { Leader is not } \\
\text { follow the rule } \\
\text { strictly }\end{array}$ & $\begin{array}{l}\text { Unlikely } \\
\text { (2) }\end{array}$ & $\begin{array}{l}\text { Major } \\
(4)\end{array}$ & 8 & M & $\begin{array}{l}\text { Leader is familiar } \\
\text { with old system }\end{array}$ & Change leader \\
\hline
\end{tabular}

Table 6. Compare before and after improvement.

\begin{tabular}{|c|c|c|c|c|c|c|c|c|}
\hline & \multicolumn{4}{|c|}{ Before Improvement } & \multicolumn{4}{|c|}{ After Improvement } \\
\hline $\begin{array}{c}\text { Key Risk } \\
\text { Indicator } \\
(\mathrm{KRI})\end{array}$ & Likelihood & Consequences & $\begin{array}{l}\text { Risk } \\
\text { Value }\end{array}$ & $\begin{array}{l}\text { Risk } \\
\text { Level }\end{array}$ & Likelihood & Consequences & $\begin{array}{l}\text { Risk } \\
\text { Value }\end{array}$ & $\begin{array}{l}\text { Risk } \\
\text { Level }\end{array}$ \\
\hline \multicolumn{9}{|l|}{ 1. Strategic Risk } \\
\hline $\begin{array}{l}\text { Users refuse } \\
\text { to use online } \\
\text { reserve system }\end{array}$ & $\begin{array}{l}\text { Likely } \\
\text { (4) }\end{array}$ & $\begin{array}{l}\text { Major } \\
\text { (4) }\end{array}$ & 16 & $\mathrm{E}$ & $\begin{array}{c}\text { Possible } \\
\text { (3) }\end{array}$ & $\begin{array}{l}\text { Major } \\
\text { (4) }\end{array}$ & 12 & $\mathrm{H}$ \\
\hline $\begin{array}{l}\text { Participants } \\
\text { don't know } \\
\text { about new } \\
\text { system }\end{array}$ & $\begin{array}{c}\text { Possible } \\
\text { (3) }\end{array}$ & $\begin{array}{c}\text { Catastrophic } \\
\text { (5) }\end{array}$ & 15 & $\mathrm{E}$ & $\begin{array}{l}\text { Unlikely } \\
\text { (2) }\end{array}$ & $\begin{array}{l}\text { Major } \\
\text { (4) }\end{array}$ & 8 & M \\
\hline $\begin{array}{l}\text { Users resist } \\
\text { using software }\end{array}$ & $\begin{array}{l}\text { Likely } \\
\text { (4) }\end{array}$ & $\begin{array}{c}\text { Catastrophic } \\
\text { (5) }\end{array}$ & 20 & $\mathrm{E}$ & $\begin{array}{c}\text { Possible } \\
\text { (3) }\end{array}$ & $\begin{array}{l}\text { Major } \\
\text { (4) }\end{array}$ & 12 & $\mathrm{H}$ \\
\hline $\begin{array}{l}\text { No survey } \\
\text { about users } \\
\text { demand }\end{array}$ & $\begin{array}{l}\text { Likely } \\
\text { (4) }\end{array}$ & $\begin{array}{l}\text { Major } \\
\text { (4) }\end{array}$ & 16 & $\mathrm{E}$ & $\begin{array}{c}\text { Unlikely } \\
\text { (2) }\end{array}$ & $\begin{array}{c}\text { Moderate } \\
\text { (3) }\end{array}$ & 6 & M \\
\hline $\begin{array}{l}\text { Unclear } \\
\text { system }\end{array}$ & $\begin{array}{c}\text { Possible } \\
\text { (3) }\end{array}$ & $\begin{array}{l}\text { Major } \\
\text { (4) }\end{array}$ & 13 & $\mathrm{H}$ & $\begin{array}{l}\text { Unlikely } \\
\text { (2) }\end{array}$ & $\begin{array}{l}\text { Major } \\
\text { (4) }\end{array}$ & 8 & M \\
\hline $\begin{array}{l}\text { Vendor is not } \\
\text { understand } \\
\text { about concept } \\
\text { of software }\end{array}$ & $\begin{array}{c}\text { Possible } \\
\text { (3) }\end{array}$ & $\begin{array}{l}\text { Major } \\
\text { (4) }\end{array}$ & 12 & $\mathrm{H}$ & $\begin{array}{l}\text { Unlikely } \\
\text { (2) }\end{array}$ & $\begin{array}{l}\text { Major } \\
\text { (4) }\end{array}$ & 8 & M \\
\hline 2. Operation Ris & & & & & & & & \\
\hline
\end{tabular}




\begin{tabular}{|c|c|c|c|c|c|c|c|c|}
\hline $\begin{array}{l}\text { Users can not } \\
\text { use online } \\
\text { reserve system }\end{array}$ & $\begin{array}{l}\text { Likely } \\
\text { (4) }\end{array}$ & $\begin{array}{l}\text { Major } \\
\text { (4) }\end{array}$ & 12 & $\mathrm{H}$ & $\begin{array}{l}\text { Unlikely } \\
\text { (2) }\end{array}$ & $\begin{array}{l}\text { Major } \\
\text { (4) }\end{array}$ & 8 & $\mathrm{M}$ \\
\hline $\begin{array}{l}\text { Correction of } \\
\text { information } \\
\text { from users } \\
\text { input }\end{array}$ & $\begin{array}{c}\text { Possible } \\
\text { (3) }\end{array}$ & $\begin{array}{l}\text { Moderate } \\
\text { (3) }\end{array}$ & 9 & M & $\begin{array}{l}\text { Unlikely } \\
\text { (2) }\end{array}$ & $\begin{array}{l}\text { Moderate } \\
\text { (3) }\end{array}$ & 6 & M \\
\hline $\begin{array}{l}\text { Duplicate or } \\
\text { spare } \\
\text { reservation }\end{array}$ & $\begin{array}{c}\text { Possible } \\
\text { (3) }\end{array}$ & $\begin{array}{l}\text { Moderate } \\
\text { (3) }\end{array}$ & 9 & M & $\begin{array}{c}\text { Unlikely } \\
\text { (2) }\end{array}$ & $\begin{array}{c}\text { Moderate } \\
\text { (3) }\end{array}$ & 6 & $\mathrm{M}$ \\
\hline \multicolumn{9}{|c|}{ 3. Financial Risk } \\
\hline $\begin{array}{l}\text { Financial } \\
\text { miscalculation }\end{array}$ & $\begin{array}{c}\text { Possible } \\
\text { (3) }\end{array}$ & $\begin{array}{l}\text { Catastrophic } \\
\text { (5) }\end{array}$ & 15 & $\mathrm{H}$ & \multirow{3}{*}{$\begin{array}{l}\text { Unlikely } \\
\text { (2) }\end{array}$} & \multirow{3}{*}{$\begin{array}{l}\text { Major } \\
(4)\end{array}$} & \multirow{3}{*}{8} & \multirow{3}{*}{$\mathrm{M}$} \\
\hline Insufficient & & & & & & & & \\
\hline $\begin{array}{l}\text { budget for } \\
\text { project that } \\
\text { cause error } \\
\text { analyse at the } \\
\text { first place }\end{array}$ & $\begin{array}{c}\text { Possible } \\
\text { (3) }\end{array}$ & $\begin{array}{c}\text { Catastrophic } \\
\text { (5) }\end{array}$ & 15 & $\mathrm{H}$ & & & & \\
\hline \multicolumn{9}{|c|}{ 4. Compliance Risk } \\
\hline $\begin{array}{l}\text { Leader is not } \\
\text { follow the rule } \\
\text { strictly }\end{array}$ & $\begin{array}{c}\text { Possible } \\
\text { (3) }\end{array}$ & $\begin{array}{l}\text { Major } \\
\text { (4) }\end{array}$ & 12 & $\mathrm{H}$ & $\begin{array}{l}\text { Unlikely } \\
\text { (2) }\end{array}$ & $\begin{array}{l}\text { Major } \\
\text { (4) }\end{array}$ & 8 & $\mathrm{M}$ \\
\hline
\end{tabular}

A use case diagram at its simplest is a representation of a user's interaction with the system that shows the relationship between the user and the different use cases in which the user is involved. A use case diagram can identify the different types of users of a system and the different use cases and will often be accompanied by other types of diagrams as well. $[19,20]$ A use case diagram for reservation system is shown in Figs. 12 and 13, respectively. 


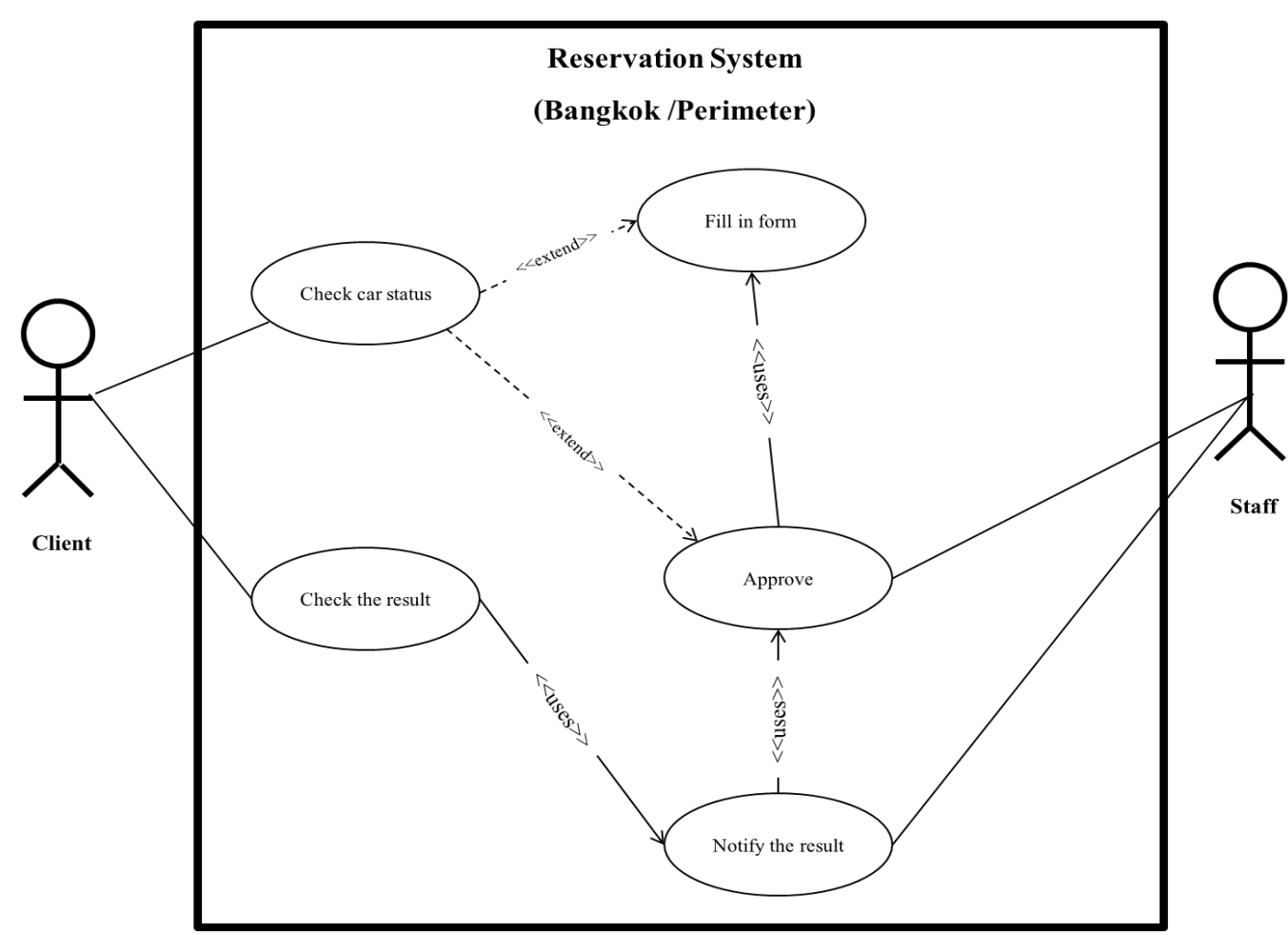

Fig. 12. Use case diagram for travelling Bangkok/Perimeter.

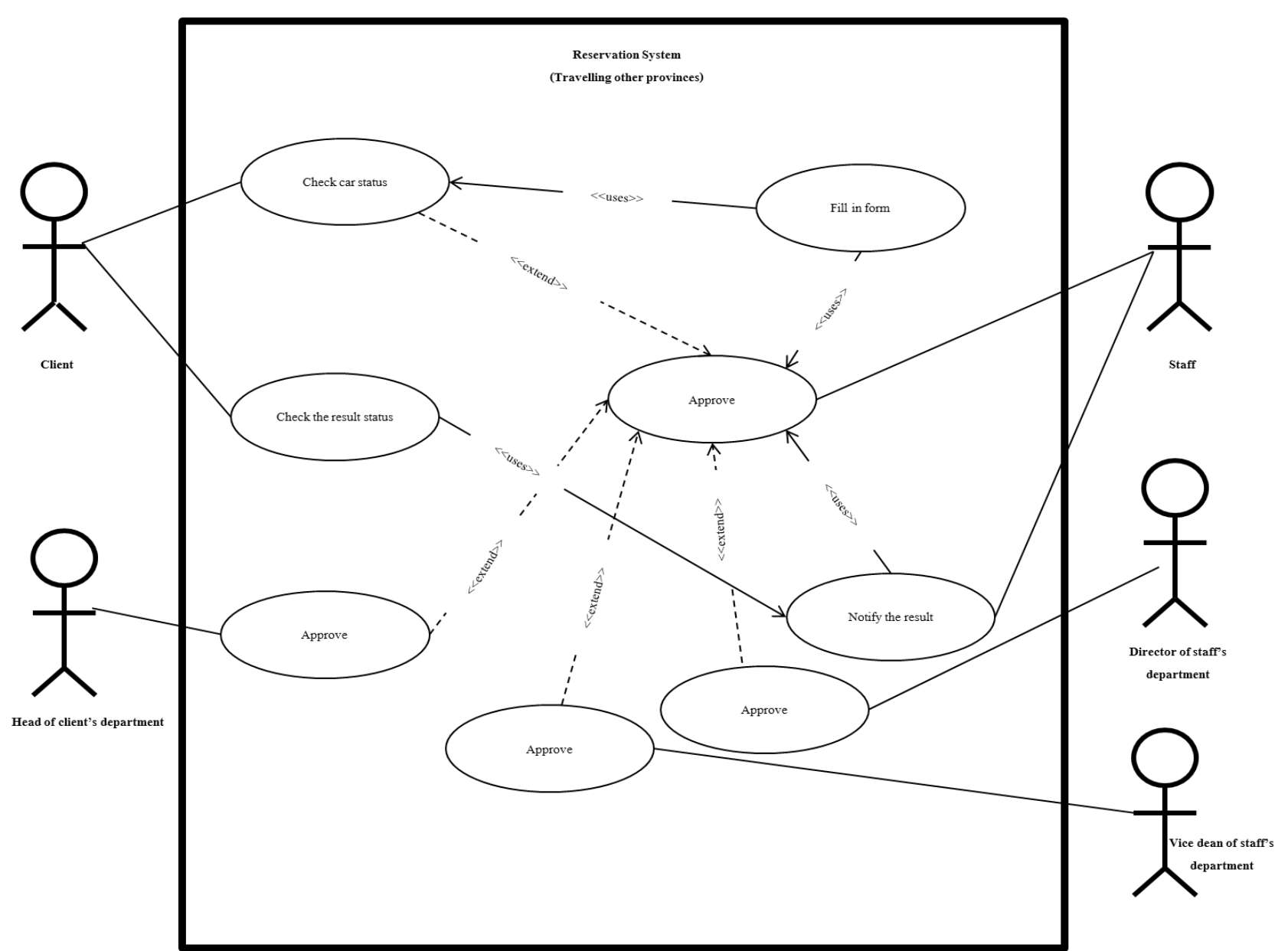

Fig. 13. Use case diagram for travelling other provinces. 
The Information Technology has checked a use case diagram that the information technology of reservation system can work appropriately. Then researcher created all example screens (requirement) to make an agreement with vendor. The example requirements are shown in Figs. 14, 15 and 16 respectively.

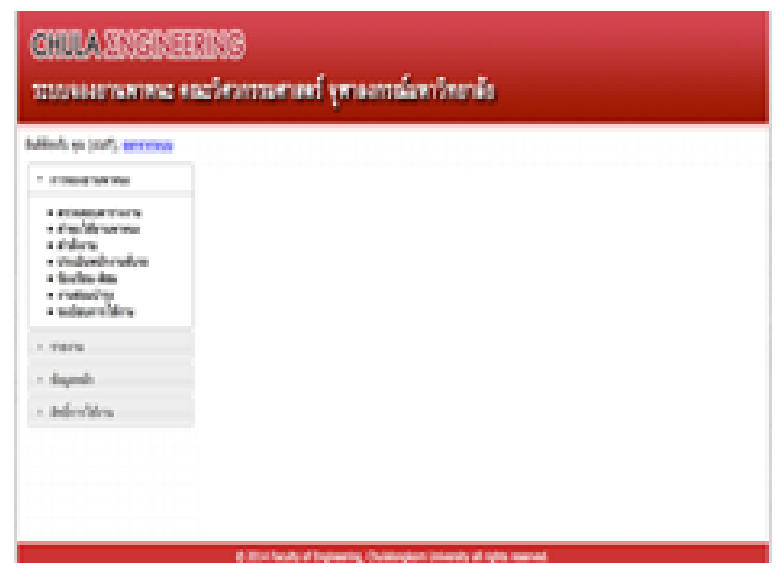

Fig. 14. Example requirement.

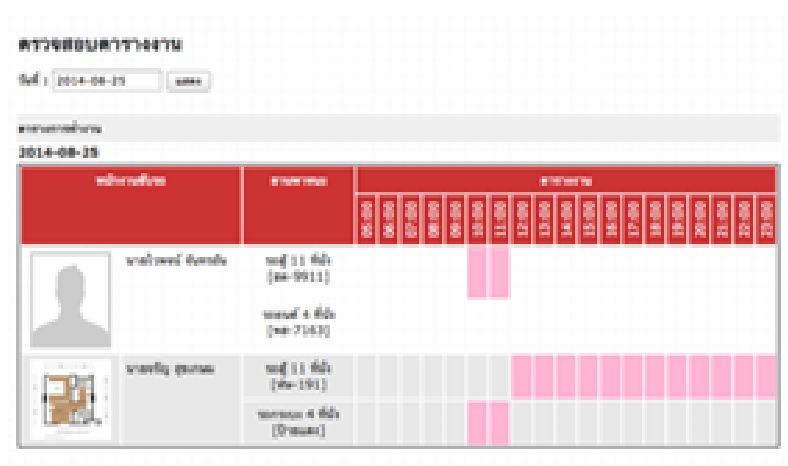

Fig. 15. Example requirement.

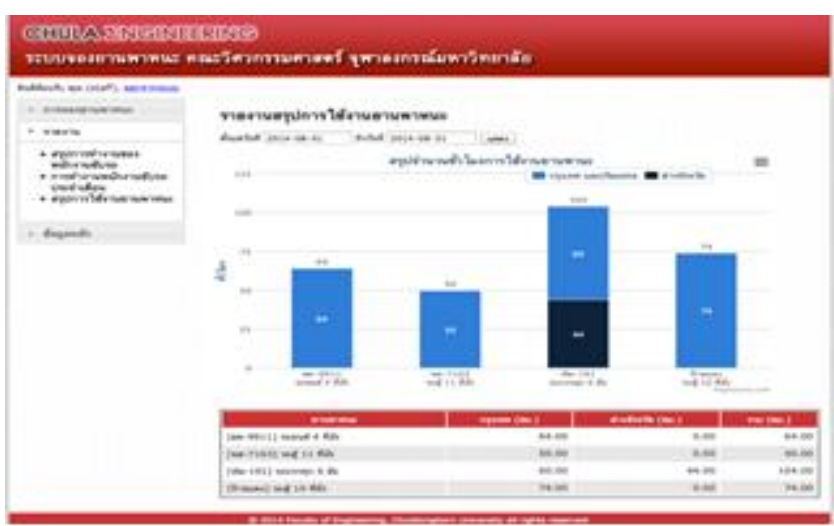

Fig. 16. Example requirement.

From Information Technology's analysis procedure, can conclude that this system will worth the investment and users will be satisfy.

\subsection{Improve Assessment for Customers}

According to the current procedures, evaluation of the drivers could be done by filling the form stuck behind the application form. Unfortunately, most of the users did not notice this form so they directly returned the form to the drivers after using the cars. The drivers then had to go to the premises department to submit this form so there were only a few car users filled the forms. As a result, there was not enough feedback to take into consideration for improving the efficiency of the process and methods. 
The researcher has searched for a suitable method that could let the executives become convenient and easy to be accessed. There are 3 methods of driver evaluation as follows:

- Evaluation of drivers on the ordering/finishing day

Since the system changed from booking by paper to the intranet system, the application form was changed to the ordering/finishing day paper instead. This ordering/finishing date paper was full of useful information and the driver evaluation form. Once the user gets in the car, the driver will give the form in order to evaluate. Next, after finishing filling the form, tear the form and drop it in a box in the car. This box can be opened only by the Head of Vehicles. Around the area where the car is, there are signs to make the users aware of the results from the questionnaires.

\section{- Evaluation through intranet reservation}

In case of intranet reservation, there is a topic for evaluation after the users have been served and was not convenient to fill the form on the ordering/finishing day. Alternatively, the users can evaluate the drivers on the intranet system.

Once the users enter the intranet system, click on the topic "Evaluate the drivers" then the history of the car usage will be shown under the names of the users. The status whether the users have filled or not is also displayed so the users can check easily by themselves. After finishing the evaluation, click "save" to keep the data and the process is complete.

- Evaluation by scanning QR CODE or entering via URLs on website

Technology has played an important role in the lives of the users so smart phones have presented as one of the main key factors in booking procedures. These phones let users read news, gain knowledge, and can access the evaluation system through QR CODE or URLs.

\subsection{Train Employees to Create Working Standard}

Training staff of the Faculty of Engineering, Chulalongkorn University for announcing the entrance of communication to use in booking cars and teach the staff to understand this procedure.

Another part of training is training drivers to understand the communication system which is used for booking and change which takes place during driver selection. This method makes it equal in working hours and wages that can be averaged among the drivers.

\section{Control}

After having improved the vehicle reservation system, the researcher collected the data about dissatisfaction and errors caused by the system and service users, and analyzed the data with Failure Mode and Effect Analysis (FMEA) to prevent recurrence of the problems.

In FMEA, errors of the process were recorded as well as their causes and consequences. The errors were sorted into 3 groups, i.e. by IT system, by vehicle and drivers, and by service users.

The researcher brainstormed with the vehicle supervisor and the organization and development officer to assess the level of severity, occurrence, and detection, in order to calculate for the risk priority number (RPN). [21]

- Severity (S) is the level of severity of an error. The assessment scale ranges from 1 to 10 . The scale of 1 refers to the lowest severity where the error does not in any way affect the provision of service. On the other hand, the scale of 10 refers to the highest severity where the service could not be operated and other organizations are affected by the error.

- Occurrence $(\mathrm{O})$ is the frequency of an error. The assessment scale ranges from 1 to 10 . The scale of 1 refers to very low occurrence, approximately 1 time per year. On the other hand, the scale of 10 refers to the highest frequency of the error, i.e. every day.

- Detection (D) is the possibility to resolve the error when one occurs. The assessment scale ranges from 1 to 10 . The scale of 1 refers to an error that a vehicle staff is able to resolve alone. On the 
other hand, the scale of 10 refers to an error that vehicle staffs and IT staffs are not able to fix, and that requires external service providers or software developers to resolve.

In order to find the RPN, the level of $\mathrm{S}, \mathrm{O}$, and $\mathrm{D}$ were multiplied before commencing the improvement. The higher RPN is, the more the system is affected.

The researcher brainstormed with relevant organizations to identify the cause of the errors and their solutions. When the solutions were found, the RPN was calculated after the improvement in order to compare the pre-improvement and post-improvement results.

Regarding the reservation errors caused by IT system, the researcher has already had a plan to tackle potential problems. The failure of the IT system needed to operate through the intranet is common. However, the frequency of the occurrence depends on the type of technology used, the operation, as well as maintenance of the service user. The vehicle reservation system is based on the IT system of the Faculty of Engineering. The causes of the problem were found to be both internal and external. Internal causes included the malfunction of the Internet transmitter and the computer, one of the most important devices for the operation, and instability of software. External causes could be the system's insufficient capacity for a large number of users (users are not just those requesting to use vehicles) or power outage.

When an error occurs, the operation of vehicle reservation is stopped and cannot be used until the IT system or the Internet resumes normal operation. Therefore, to tackle this risk, the principle of business continuity plan (BCP) is applied. The BCP will be used at 3 stages: before the incident, during the incident, and after the incident.

Human errors such as supervisor's failure to examine the operation of vehicle operator that results in non-transparency, the leave of vehicle operators that results in discontinued operation, unpunctuality of the vehicle operator and the service users that affects the operation of the next vehicle, and users' failure to cancel the reservation that make other users unable to use the vehicle. Human errors' RPN can be compared between pre-improvement and post-improvement as in Table 7.

Table 7. Failure Mode and effect Analysis.

\begin{tabular}{|c|c|c|c|c|c|c|c|c|c|c|c|c|}
\hline \multirow{2}{*}{ Process } & \multirow{2}{*}{$\begin{array}{c}\text { Potential } \\
\text { Failure Mode }\end{array}$} & \multirow{2}{*}{$\begin{array}{l}\text { Potential } \\
\text { Failure } \\
\text { Effects }\end{array}$} & \multirow{2}{*}{$\begin{array}{l}\text { Potential } \\
\text { Causes }\end{array}$} & \multirow{2}{*}{ Action Taken } & \multicolumn{4}{|c|}{$\begin{array}{c}\text { Before } \\
\text { Improvement } \\
\end{array}$} & \multicolumn{4}{|c|}{$\begin{array}{c}\text { After } \\
\text { Improvement }\end{array}$} \\
\hline & & & & & $\mathrm{S}$ & $\mathrm{O}$ & $\mathrm{D}$ & $\begin{array}{l}\mathrm{RP} \\
\mathrm{N}\end{array}$ & $\mathrm{S}$ & $\mathrm{O}$ & $\mathrm{D}$ & RPN \\
\hline \multirow[t]{3}{*}{$\begin{array}{l}\text { Information } \\
\text { Technology }\end{array}$} & $\begin{array}{l}\text { Internet or } \\
\text { Intranet } \\
\text { system is } \\
\text { unavailable. }\end{array}$ & $\begin{array}{l}\text { Can't } \\
\text { reservation } \\
\text { vehicles. }\end{array}$ & $\begin{array}{l}\text { Lack of } \\
\text { maintenance. }\end{array}$ & $\begin{array}{l}\text { The backup plans in } \\
\text { case of errors can be } \\
\text { divided into } 3 \text { stages. } \\
\text { Pre-incident plan } \\
\text { includes regular } \\
\text { maintenance of the } \\
\text { system. During- } \\
\text { incident plan includes } \\
\text { the fastest solution and } \\
\text { introduction of paper- } \\
\text { based system. Post- } \\
\text { incident plan includes } \\
\text { entering the paper- } \\
\text { based data into the } \\
\text { system. }\end{array}$ & 7 & 2 & 4 & 56 & 4 & 1 & 2 & 8 \\
\hline & $\begin{array}{l}\text { The } \\
\text { statistical } \\
\text { reservation } \\
\text { system error. }\end{array}$ & $\begin{array}{l}\text { Unfairly } \\
\text { allocate } \\
\text { driver and } \\
\text { car. }\end{array}$ & $\begin{array}{l}\text { Database } \\
\text { error. }\end{array}$ & $\begin{array}{l}\text { Inform vendor to } \\
\text { repair system. }\end{array}$ & 6 & 4 & 2 & 48 & 6 & 2 & 2 & 24 \\
\hline & $\begin{array}{l}\text { Car and } \\
\text { driver } \\
\text { schedule } \\
\text { error. }\end{array}$ & $\begin{array}{l}\text { Wrongful } \\
\text { reservation } \\
\text { system. }\end{array}$ & $\begin{array}{l}\text { Database } \\
\text { error. }\end{array}$ & $\begin{array}{l}\text { Manual reservation } \\
\text { instead information } \\
\text { system. }\end{array}$ & 5 & 2 & 2 & 12 & 4 & 2 & 2 & 16 \\
\hline Car's Staff & $\begin{array}{l}\text { Head of staff } \\
\text { doesn't } \\
\text { check } \\
\text { operation of } \\
\text { car's staff } \\
\text { regularly. }\end{array}$ & $\begin{array}{l}\text { Unclear } \\
\text { reservation } \\
\text { system. }\end{array}$ & $\begin{array}{l}\text { Car's staff is } \\
\text { not } \\
\text { transparent } \\
\text { for } \\
\text { reservation. }\end{array}$ & $\begin{array}{l}\text { Head of car's staff } \\
\text { always checks } \\
\text { operation of car's staff. }\end{array}$ & 7 & 2 & 2 & 28 & 3 & 1 & 1 & 3 \\
\hline
\end{tabular}




\begin{tabular}{|c|c|c|c|c|c|c|c|c|c|c|c|c|}
\hline & $\begin{array}{l}\text { Car's staff } \\
\text { absent for } \\
\text { work. }\end{array}$ & $\begin{array}{l}\text { Delay in } \\
\text { operation } \\
\text { process. }\end{array}$ & $\begin{array}{l}\text { Car's staff } \\
\text { absent for } \\
\text { work. }\end{array}$ & $\begin{array}{l}\text { Train another staff for } \\
\text { work when official } \\
\text { car's staff absent. }\end{array}$ & 3 & 2 & 2 & 12 & 1 & 1 & 1 & 1 \\
\hline Customer & $\begin{array}{l}\text { Unpunctual } \\
\text { of } \\
\text { appointment. }\end{array}$ & $\begin{array}{l}\text { Next } \\
\text { appointment } \\
\text { is late. }\end{array}$ & $\begin{array}{l}\text { Unpunctual } \\
\text { of customer. }\end{array}$ & $\begin{array}{l}\text { Inform customer } \\
\text { before } 30 \text { minutes of } \\
\text { appointment. }\end{array}$ & 4 & 5 & 2 & 40 & 3 & 2 & 2 & 12 \\
\hline
\end{tabular}

After the brainstorm to find the causes and solutions to address the error and improve the service, it was found that RPN values were lower in every item of errors and problems, resulting in less frequency of error occurrence, more stability, and higher satisfaction of users.

\section{Conclusion}

After improvement, the car users were satisfied with the service (1-5 Likert scale) increased by $30 \%$ from 3.35 as the medium level to 4.37 as the good level.

The process reservation time of travelling in Bangkok and perimeters in group $1^{\text {st }}$ is deceased from 496.4 minutes to 4.3 minutes and number of activity is decreased from 9 activities to 4 activities. And group $2^{\text {nd }}$ is deceased from 496.4 minutes to 485.65 minutes and number of activity is decreased from 9 activities to 7 activities.

The process reservation time of travelling others provinces is decreased from 1468 minutes to 967.6 minutes and number of activities is decreased from 14 activities to 10 activities.

The time of check back system is decreased by $87 \%$ from 15.5 minutes to 2 minutes and number of non-value added activities is reduced from 2 activities to no non value added activity as shown in Fig. 17.

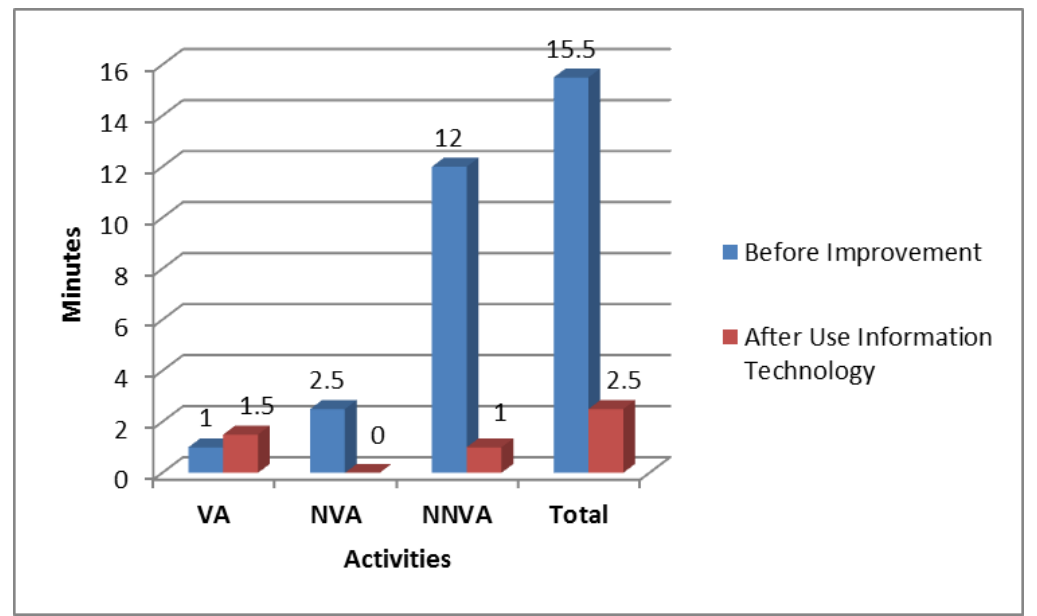

Fig. 17. Number of activity in check back process.

The benefit from the application of QFD with SERVQUAL and information technology follow from the Lean Six Sigma and 5D step is they will receive the service with quality that meet to their needs. Organization also gain benefit from cost and time saving in term of product design and development, as well. Moreover, staff can work as good team work with best performance with the systematic information system.

\section{References}

[1] N. Thawesaengskulthai, "Technology and innovation management," unpublished.

[2] J. A. Fitzsimmons, M. J. Fitzsimmons, and S. K. Bordoloi, Service Management: Operations, Strategy, Information Technology, 8th ed. New York, USA: McGraw Hill/Irwin, 2014.

[3] A. Tagsakul, "Waste Reduction in Installation Process of Vehicles Gas System by Lean Six Sigma Concept," in Proc. IE Network, Khonkaen, 2009.

[4] S. Vivitchanont, "Defect reduction in precast concrete production," Master of Industrial Engineering thesis, Faculty of Engineering, Chulalongkorn University, Bangkok, Thailand, 2010. 
[5] Y. Monden, Toyota Production System: An Integrated Approach to Just-In-Time, 2nd ed. Press Institute of Industrial Engineers, 1993.

[6] M. Lawrence, "Lean six sigma: the Contribution to business excellence," International Journal of Lean Six Sigma, vol. 2, no. 2, pp. 118-131, 2011.

[7] B. Ictenbas and E. Hande, "Quality function deployment as a strategic planning tool," International Journal of Social Sciences and Humanity Studies, vol. 3, no. 2, 2011.

[8] Y. Akao and G. H. Mazur, "QFD: Past, present, and future," International Journal of Quality \& Reliability Management, vol. 20, no. 1, pp. 20-35, 2003.

[9] M. Hussain, L. Tsironis, and M. M. Ajmal, "A QFD strategy for improving customer satisfaction: case study of telecom companies of Pakistan," Asian Journal on Quality, vol. 12, no. 3, pp. 282-295, 2011.

[10] A. K. Ikiz and A. Masoudi, "A QFD and SERVQUAL approach to hotel service design," Issetme Fakültesi Dergisi, pp. 17-31, 2008.

[11] I. Gremyr and H. Raharjo, "Quality function deployment in healthcare: A literature review and case study," International Journal of Health Care Quality Assurance, vol. 26, no. 2, pp. 135-146, 2013.

[12] L. Berry and A. Parasuraman, Marketing Services: Competing Through Quality. Free Press, 1991.

[13] K. C. Tan and T. A. Pawitra, "Integrating SERVQUAL and Kano's model in to QFD for service excellence development," Managing Service Quality, pp. 418-430, 2001.

[14] S. Sahney, D. K. Banwet, and S. Karunes, "A SERVQUAL and QFD approach to total quality education: A student perspective," International Journal of Productivity and Performance Management, vol. 53, pp. 143-166, 2004.

[15] W. Yothinsirikul, "Application of quality function deployment and SERVQUAL for service encounter," Master of Industrial Engineering thesis, Faculty of Engineering, Chulalongkorn University, Bangkok, Thailand, 2013.

[16] C. Lovelock and J. Wirtz, Service Marketing: People, Technology, Strategy, 7th ed. Pearson Prentice Hall, 2012.

[17] J. Maneenak, Enterprise Wide-Risk Management. Bangkok, Thailand: Final publisher, 2007.

[18] S. Gopalakrishnan, P. Bierly, and H. Kessler, "A reexamination of product and process innovations using a knowledge-based view," Journal of High Technology Management Research, vol. 10, no. 1, pp. $147-$ 166, 1999.

[19] N. Ibrahim, R. Ibrahim, M. Z. Saringat, D. Mansor, and T. Herawan, "Consistency rules between UML use case and activity diagrams using logical approach," International Journal of Software Engineering and its Applications, vol. 5, no. 3, pp. 119-134, 2011.

[20] K. Ploypanichjareon, Quality Control, 1st ed. Bangkok, Thailand: Technology Promotion Association (Thailand-Japan), 2007.

[21] L. S. Lipol and J. Haq, "Risk analysis method: FMEA/FMECA in the organization," International Journal of Basic \& Applied Sciences, vol. 11, no. 5, pp. 74-82, 2011. 